\title{
Chemical Composition of Fillets of Mirror Crossbreds Common Carp (Cyprinus carpio L.)
}

\author{
Hana Buchtová1, Zdeňka Svobodová1, Martin Kocour², Josef Velíšek ${ }^{2}$ \\ ${ }^{1}$ Department of Meat Hygiene and Technology, Faculty of Veterinary Hygiene and Ecology, \\ University of Veterinary and Pharmaceutical Sciences in Brno, Czech Republic \\ ${ }^{2}$ Research Institute of Fish Culture and Hydrobiology in Vodňany, Faculty of Fisheries and Protection of Waters, \\ University of South Bohemia in České Budějovice, Czech Republic
}

Received March 4, 2010

Accepted June 15, 2010

\begin{abstract}
This paper presents the results of a study dealing with chemical composition of fillets and fatty acid composition (saturated fatty acid: SFA, monounsaturated fatty acid: MUFA, polyunsaturated fatty acid: PUFA) of lipids. Three groups of the mirror hybrid carp in age of three years: M $2 \times$ L15 - the Hungarian Szarvas mirror carp (M2) and the Hungarian hybrid mirror strain (L15), M2 $\times$ DOR 70 (the Israeli breed - DOR70), M2 × M72 (Northern mirror carp - M72) were compared with: the pure breed M2 and scaly hybrid ROP $\times$ TAT - the Ropsha (ROP) and the Tata (TAT) carp. ROP $\times$ TAT hybrid fillets contained (in $\left.\mathrm{g} \cdot \mathrm{kg}^{-1}\right)$ more $(P<0.01)$ dry matter $(283.1 \pm 23.87)$ and lipids $(99.3 \pm 30.60)$. Fat in all of the monitored carp groups was made up of more than $50 \%$ of MUFA (from 51 to 64\%), $25-29 \%$ of SFA and $10-22 \%$ of PUFA. Fillets of mirror hybrids M2 $\times$ DOR70, M2 $\times$ M72 and breed M2 contained less lipids $(P<0.01)$, less MUFA sum $_{(}(P<0.01)$, particularly less oleic acid $\left(\mathrm{C} 18: 1_{n-9}\right)$, and more PUFA PU $_{-3}(P<0.01)$, more eicosapentaenoic acid $\left(\mathrm{C} 20: 5_{\mathrm{n}-3}\right)$ and docosahexaenic acid $\left(\mathrm{C} 22: 6_{\mathrm{n}-3}\right)$. The differences in fatty acid profile can be related to the different genetic effects of different groups of common carp.
\end{abstract}

Fish meat, lipid quality, chemical indicator, fatty acid

Fish in general and ocean fish including shellfish in particular are considered an important source of essential n-3 polyunsaturated fatty acids (PUFA $\left.{ }_{n-3}\right)$, i.e. $\alpha$-linolenic acid, eicosapentaenic acid (EPA) and docosahexaenic acid (DHA) (Ackman 2000). High concentrations of PUFA ${ }_{n-3}$ in foodstuffs are favourable for human health, which has been demonstrated in clinical experiments (Simopoulos 1997). The long-chain PUFA ${ }_{n-3}$ have antiatherosclerotic effects and also beneficial effects on several other diseases (Steffens and Wirth 2007).

N-3 fatty acids are also present in lipids of freshwater fish (Ackman 2002). However, quantity of these acids varies largely in dependence on the fish species (herbivorous, omnivorous or carnivorous), if they are wild fish or farm-raised, on the age of fish and on origin of diets (natural food or cereal supplement) and its composition (rich primarily in PUFA $_{\mathrm{n}-3}$ or saccharides) (Steffens 1997). Fresh-water carp may be as nutritionally valuable as ocean fishes (Steffens 1977). Carps reared in ponds on natural food had high content of n-6 as well as n-3 fatty acids in their muscle triacylglycerols, carps fed with a suplamentary wheat diet had lower levels of those essential fatty acids (Steffens and Wirth 2007). Donmez (2009) found total EPA and DHA fatty acids concentrations at the level of $14.96 \mathrm{~g} \cdot 100^{-1} \mathrm{~g}$ fat in wild carps. On the other hand, Ackman (2002) reported EPA and DHA concentrations in farmed carp as low as $0.35 \mathrm{~g} \cdot 100^{-1}$ fat. The fatty acid composition in the muscle of carps can be significantly influenced by the feeding period and the season of the year (Guler et al. 2008). According to Mareš et al. (2009), the presence of cyanobacterial water bloom had a significant effect on the content of individual fatty acids analysed in muscles of the farmed carps. Significant $(P<0.05)$ differences were found in the ratio of PUFA ${ }_{n-3 / n-6}$. In the case of common carp, these differences were based 
on changes in the content of PUFA ${ }_{n-3}$ and ${ }_{n-6}$, in case of the silver carp only in the content of PUFA ${ }_{n-6}$ that increased during the exposure of fish to the cyanobacterial water bloom. In addition, environmental factors, especially water temperature, influenced the fatty acid composition of plankton (Guo et al. 2008).

The scaly hybrid is commonly farmed for commercial purposes and served as a control group (e.g. Linhart et al. 2002; Kocour et al. 2005a) for comparison of growth and survival of the mirror groups.

The aim of this study was to evaluate the fatty acid profile in the intramuscular fat of different carp groups and to find out whether there is a difference between the sexes.

\section{Materials and Methods}

\section{Starting material and processing}

The performance test of mirror common carp groups started in 2003 at the fishfarming company Rybníkářství Tábor, a. s., when fish in the $\mathrm{K}_{0}$ stage were stocked in ponds. The test was finished at the end of the 2005 in vegetation period, in which the fish reached the harvest size. The fish were tested in ponds and, to guarantee the objectivity of results of performance, growth and survival, an internal control group of carp scaly hybrid was used (Linhart et al. 2002; Kocour et al. 2003; 2005ab). For the experiment, 15 females of Hungarian Szarvas mirror carp (M2) were used in the maternal position. The females were crossed with 25 males from each out of 4 various breeds (top-crossing) using artificial reproduction method described by Kocour et al. (2005a). Paternal breeds were the Hungarian Szarvas mirror carp (M2) for pure breed production, Hungarian Szarvas two-line hybrid strain (L15), the Israeli breed (DOR70) and the Northern mirror carp (M72). The scaly hybrid of the Ropsha (ROP) and the Tata (TAT) carp was used as a control. The fish were reared under standard pond management conditions in the Czech Republic. For their growth, fish had their natural diet available in the ponds (plankton, benthos) over 3 vegetation seasons. Fish usually do not feed in the winter (November - February) period. In the first vegetation season, the fish were fed supplementary feed mix KP1 $3 \times$ a week starting when the fish was 2 months old. In the second vegetation period, the supplementary feed mix was replaced with uncrushed wheat, which was also fed to the fish in the third vegetation period. The supplementary feed was fed $3 \times$ weekly throughout the experiment. During the experiment (before and after each vegetation period), data on growth (weight) and survival of fish were recorded.

The final evaluation of the experiment was made at the end of the 2005 vegetation period in three-year-old fish $\left(\mathrm{K}_{3}\right)$. From the pond with the highest mean fish weight, 40 carp from each of the 5 groups (i.e. the ROP $\times$ TAT control, M2 pure breed, experimental hybrid M2 $\times$ L15, M2 $\times$ DOR70, M2 $\times$ M72) were randomly chosen for chemical examination (a total of 200 fish). Fish carcasses were evaluated according to Gela and Linhart (2000) at University of South Bohemia in České Budějovice and Research Institute of Fish Culture and Hydrobiology in Vodňany, Czech Republic.

\section{Chemical analysis}

Four indicators of basic chemical composition (in $\mathrm{g} \cdot \mathrm{kg}^{-1}$ ) were determined in fish meat: content of dry matter (DM), crude protein (CP), fat (F) and ash (A). The DM content was determined gravimetrically following the reference method (International Standard 1997) for determination of moisture content in flesh by drying the sample with sand up to constant weight at $+103 \pm 2{ }^{\circ} \mathrm{C}$. The $\mathrm{CP}$ content was determined as the amount of organically bound nitrogen (recalculating coefficient $f_{1}=6.25$ ) using analyzer Kjeltec 2300 (FOSS Analytical $\mathrm{AB}$, Sweden, Högänas) following the procedure recommended by the producer (Application note 2003). The content of $\mathrm{F}$ was determined quantitatively by extraction in diluents using Soxtec (Tecator, Sweden) using the method following recommendation of the producer (Application note 1990). The content of A was determined gravimetrically by burning the weighed sample in muffle oven (Elektro LM 212.11 , Germany) at $550{ }^{\circ} \mathrm{C}$ until black carbon particles disappeared (International Standard 1998).

To study fatty acid composition in fish meat, 5 male carp and 5 female carp fillets were randomly chosen from each of the groups (a total of 50 fillets). An aliquot $(50 \mathrm{~g})$ of each sample (middle part of the fillet) was used for fat determinations. The determination of fatty acid composition was performed by gas chromatography using HP 4890 (Hewlett-Packard, USA) apparatus with flame ionization detector (FID) and capillary column Omega Wax TM250 $(30 \mathrm{~m} \times 0.25 \mathrm{~mm} \times 0.25 \mu \mathrm{m})$ following extraction with a mixture of methanol and chloroform (Fols ch et al. 1957). The optimum temperature gradient was $140{ }^{\circ} \mathrm{C}$ to $240{ }^{\circ} \mathrm{C}\left(5^{\circ} \mathrm{C} / \mathrm{min}\right)$. The injector temperature was $280^{\circ} \mathrm{C}$, the FID temperature was $300^{\circ} \mathrm{C}$. Nitrogen was used as the carrier gas.

Basic statistical values (means, S.D.) of the variables measured were processed in Excel 97. Statistical significance was evaluated using the multifactorial analysis of variance ANOVA Statistica 7.0 (StatSoft CR, s.r.o., Praha, Czech Republic).

\section{Results and Discussion}

The traditional approach to the rearing of common carp (Cyprinus carpio L.) in the Czech Republic is based on foods naturally occurring in ponds (zooplankton, benthos). The energy-producing component of their diet is supplemented with untreated cereals 


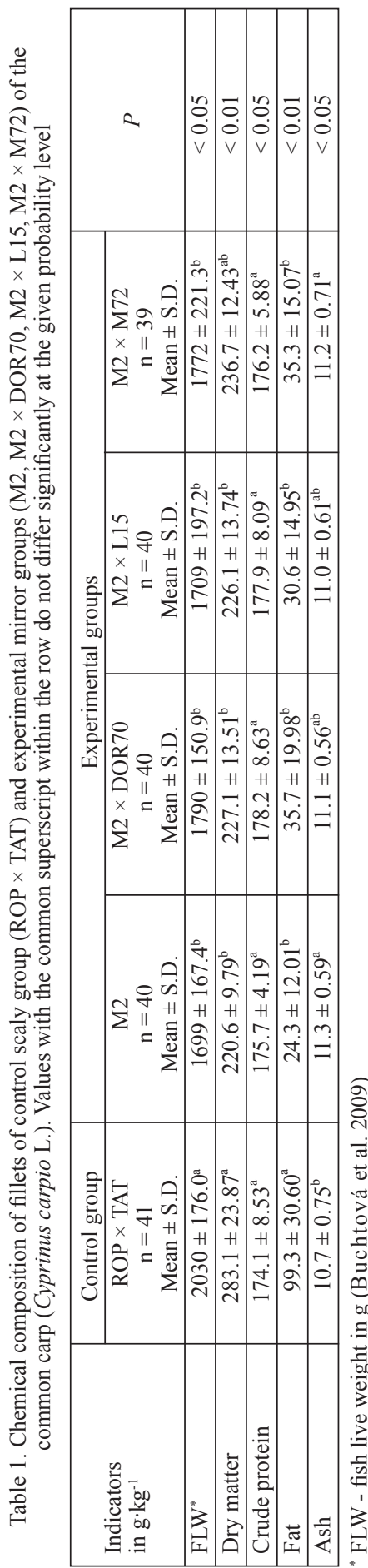

(wheat). The preference for a feed rich in saccharides leads to an increase in the percentage of the oleic acid $\left(\mathrm{C} 18: 1_{\mathrm{n}-9}\right)$ in body lipids of the fish, which is produced in the organism by desaturation and elongation of saturated fatty acids (SFA). At the same time, there is a decrease in the percentage of PUFA $_{n-3}$ (Fajmonová et al. 2003; Buchtová et al. 2007).

Regarding basic chemical composition of muscle tissue, we did not expect to find any major differences in percentages of the nutrients monitored between groups of carp tested in our experiment because the fish came from the same environment, were of the same species, age, and had the same access to the same food and supplements. Chemical composition of sexually mature healthy fish is more markedly affected by the ongoing reproductive cycle (Lachowicz and Kołakowski 2001). Quality of edible parts is also affected in fastgrowing fish because the change in growth capability is associated with a greater food intake and increased nutrient conversion (Steffens 1974).

We found differences in fillet chemical composition between the ROP $x$ TAT control hybrid and the mirror experimental carp groups. ROP $\times$ TAT hybrid fillets (the highest final weight $2030 \pm 176.00 \mathrm{~g}, P<0.05)$ contained more $(P<0.01)$ dry matter $\left(283.1 \pm 23.87 \mathrm{~g} \cdot \mathrm{kg}^{-1}\right)$ and lipids $\left(99.3 \pm 30.60 \mathrm{~g} \cdot \mathrm{kg}^{-1}\right)$ and non-significantly less nitrogenous substances (Table 1). Similar results were reported for the rainbow trout by Corraze et al. (1993). Higher deposition of lipids in meat of ROP $\times$ TAT hybrids and better growing are probably consequential to their preference for high-energy cereals in feed and/or to a genetically-based difference in metabolism. Chemical compositions of fillets from mirror carp hybrids (M2 $\times$ DOR70, M2 $\times$ L15, M2 $\times$ M72) and from the pure line carp (M2) were practically identical. All mirror groups showed comparable weight at harvest.

Lipids in all groups of carp examined consisted of more than $50 \%$ of MUFA (from 51 to $64 \%$ ). SFA sum $_{\text {sum }}$ and PUFA $_{\text {sum }}$ made up 25 to $29 \%$ and 10 to $22 \%$, respectively. The oleic acid $\left(\mathrm{C} 18: 1_{\text {n-9 }}\right)$ followed (in descending order) by palmitic acid (C16:0), palmitoleic acid (C16:1), stearic acid (C18:0), linoleic acid (C18:2 acid $\left(\mathrm{C} 20: 1_{n-9}\right), \alpha$-linolenic acid $\left(\mathrm{C} 18: 3_{\mathrm{n}-3}\right)$ and myristic acid (C14:0) were the most abundant among lipids. Concentrations of the remaining fatty acids were below $1 \%$ (Table 2). The reason for unfavourable composition of fatty acid spectrum in lipids of all carp groups can be accounted to the type of food dominating in the diet. Steffens and Wirth (2007) reported that different methods of rearing and feeding cause substantial variations in the fatty acid composition of pond fish. 
T⿱乛龰

兽

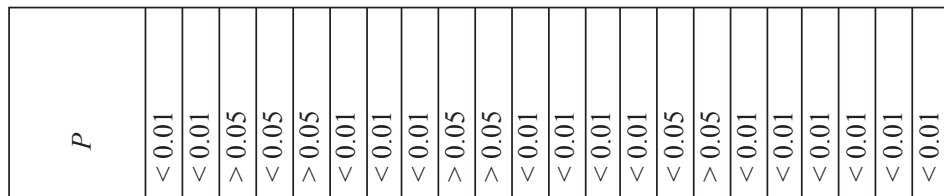

고

우을

충

铝

$4 \times$

공

$\sum$

过

응

空施氜

它

密焉离

恶语

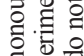

음음

政

$\varangle$

氛是龵

近要

$5 \times 3$

ते

要

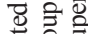

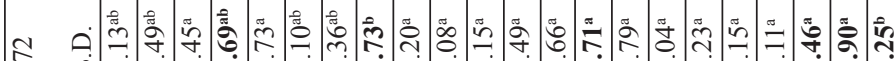

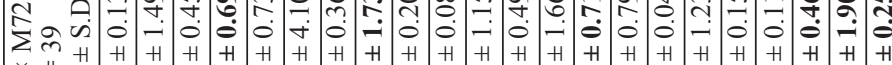

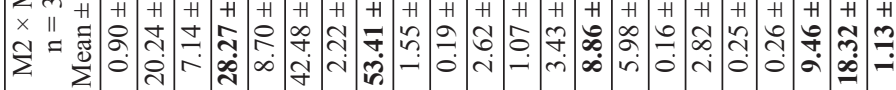

荧

t艹

뭉ㅇㅇ

氙

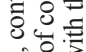

की

昰:

空要

要

ำ

爱

离.思约

젱

究

응

$\Xi \mathbb{1}^{\circ}$

范 。

:

웅

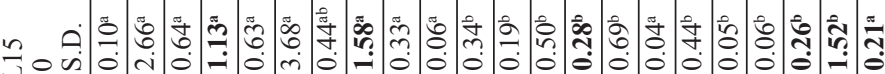

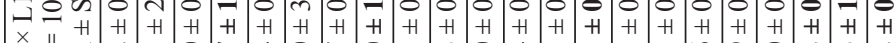

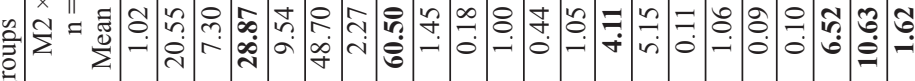
无

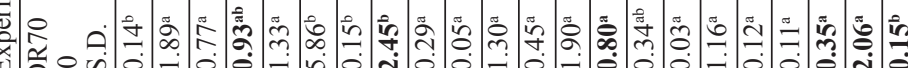

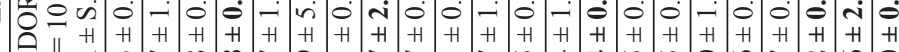

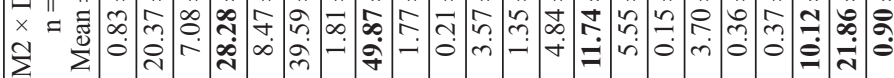

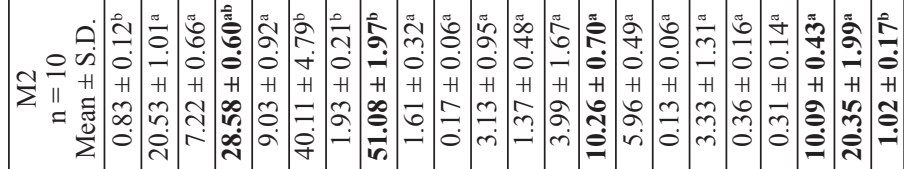

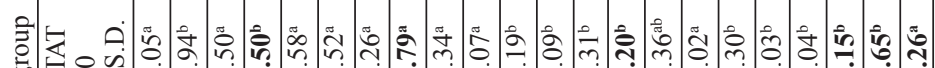

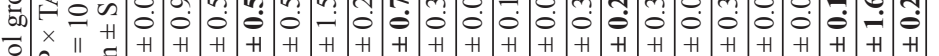

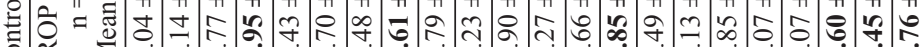
Uे

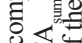

곤잉

을

窇文

प

고 
Marketable carp reared on the basis of natural food in ponds exhibit high contents of n-6 as well as n-3 fatty acids, on the other hand carp fed supplementary wheat, which is characterized by a low content of PUFA $_{n-3}$ (Steffens et al. 1998), resulted in somewhat lower concentrations of these acids and higher oleic acid content.

The cereal-based supplement offered was probably sought after more readily $(P<0.05)$ by the faster growing scaly hybrid ROP $\times$ TAT. Hence, lipids of this hybrid contained the highest concentrations $(51.70 \pm 1.52 \%)$ of the oleic acid $\left(\mathrm{C} 18: 1_{\mathrm{n}-9}\right)$. With respect to lipid quality, experimental mirror carp M2 $\times$ DOR70, pure line M2 carp and mirror carp M2 $\times$ M72 demonstrated a more desirable fatty acid composition than carp from the control ROP $\times$ TAT group. Although their fillets contained less $(P<0.01)$ lipids, they also contained less $(P<0.01)$ MUFA $_{\text {sum }}$, less oleic acid $\left(\mathrm{C} 18: 1_{\mathrm{n}-9}\right)$, and more $(P<0.01)$ PUFA $_{\mathrm{n}-3}$, more eicosapentaenoic acid $\left(\mathrm{C} 20: 5_{\mathrm{n}-3}\right)$ and docosahexaenoic acid $\left(\mathrm{C} 22: 6_{\mathrm{n}-3}\right)$, while percentages of the essential $\alpha$-linolenic acid $\left(\mathrm{C} 18: 3_{\mathrm{n}-3}\right)$ in lipids of all carp groups were identical. Derivates of these PUFA $_{n-3}$, so-called eicosanoids (especially prostacyclins), play a positive role in the prevention of cardiovascular diseases (Steffens 1997). In contrast to ROP $\times$ TAT hybrids, the slowly growing mirror carp groups probably ingested in higher rate natural pond foods containing more EPA and DHA. Concentrations of these fatty acids are high especially in zooplankton and chironomid larvae (Steffens et al. 1998). According to Guo et al. (2008), fatty acid composition of plankton varies with seasonal changes. The content of PUFA ${ }_{n-3}$ (especially DHA) is high when cryptophytes and DHA-rich copepods become an important group of plankton. However, the fatty acid profiles of the fish larvae did not always agree with those of the plankton.

Fatty acid composition of M2 $\times$ L15 mirror carp was demonstrably different from FA composition of other mirror carp groups (comparable growth intensity, content of lipids and other nutrients in muscle tissues) particularly in lower $(P<0.01)$ percentage of PUFA ( ${ }_{n-3}$ and ${ }_{n-6}$ fatty acids), and was almost identical with lipid composition of the control ROP $\times$ TÂT hybrids. The exception was the palmitic acid (C16:0) concentration, which was higher $(P<0.01)$ in M2 $\times$ L15 mirror carp, with consequently higher $\mathrm{SFA}_{\text {sum }}(P<0.05)$. This finding may be connected with a change in nutrient habits of M2 $\times$ L15 carp with higher cereal supplement ratio in the diet. Another hypothetical reason for differences in fatty acid composition may lie in differences in genetic specifications between groups tested, which could have resulted in differences in activity levels of the appropriate desaturation and elongation enzymes. Significant difference in PUFA content between crossbreds was found in a previous study in common carp (Buchtová et al. 2007). Hoffman and Prinsloo (1995) investigated fatty acid profile in 4 different genetic strains of Clarias gariepinus grown under identical environmental conditions. Authors found significant differences in the content of $\mathrm{C} 16: 0, \mathrm{C} 18: 1_{n-9}, \mathrm{C} 22: 5_{\mathrm{n}-3}, \mathrm{C} 22: 6_{\mathrm{n}-3}$ and ${ }_{\mathrm{n}-3 / \mathrm{n}-6}$ ratio. In another experiment, the effect of nutrition on the fatty acid profile in one selected strain was also verified. Similarly, Erickson (1992) found differences in content of PUFA, peroxidizability index for susceptibility of UFA to oxidize, and ratio of PUFA/ $\alpha$-tocopherol equivalents when comparing three strains of channel catfish (Ictalurus punctatus).

Significant differences in the fat between female and male carp were found in one case. Male M2 $\times$ M72 mirror carp fat contained less eicosenoic acid (C20:1) compared to their female counterparts $(1.92 \pm 0.22 \%$ vs. $2.53 \pm 0.10 \%, P<0.01)$. No other sex-related differences in FA concentrations were found.

The results show that differences in the fatty acid profile in various genetic groups of common carp may exist. The lower quality of fatty acid profile in carp reared under pond management may be ascribed to the negative effect of cereal supplementation and/or to the genetic effects. The basic prerequisite for sustainable carp production with desirable muscle lipid compositions should be seen in the development of new feeding and breeding procedures. Supplemental feeding should contain more vegetable oils that 
will help to increase PUFA $_{\text {sum }}$ concentrations in muscle lipids of the cyprinids, similarly to the approach used in ocean and fresh-water salmoniform fish (Zelenka et al. 2003; Steffens and Wirth 2007). Salmoniform fish feeds commonly contain e.g., rape seed or flax seed oil as substitutes for fish oil, which is very expensive and in short supply. At the same time, experiments are under way to study sesamin, a biologically active substance present in sesame oil, which significantly effects enzyme activity and enhances fatty acid elongation and desaturation capability (Trattner et al. 2008). With regard to breeding, strains and/or crossbreds with more optimal fat metabolism should be looked for, together with possibilities for an effective selection program.

\section{Chemické složení filetů lysých hybridů kapra obecného (Cyprinus carpio L.)}

Studie prezentuje výsledky chemického složení filetů včetně složení mastných kyselin tuku (nasycené mastné kyseliny: SFA, mononenasycené mastné kyseliny: MUFA, polynenasycené mastné kyseliny: PUFA). K vyšetření byly použity filety tř́ lysých hybridů kapra ve věku tř́ let: M2 × L15 - mad'arský "Szarvas" lysec (M2) a mad'arská lysá linie (L15), M2 × DOR70 izraelské plemeno (DOR70) a M2 × M72 severský lysý kapr (M72), které byly srovnávány s filety čisté linie M2 a šupinatým hybridem ropšínského (ROP) a tatajského plemene (TAT). Filet hybrida ROP $\times$ TAT obsahoval více $(P<0.01)$ sušiny $(283.1 \pm$ $\left.23.87 \mathrm{~g} \cdot \mathrm{kg}^{-1}\right)$ a lipidů $\left(99.3 \pm 30.60 \mathrm{~g} \cdot \mathrm{kg}^{-1}\right)$. Tuk všech sledovaných skupin kapra byl složen z více jak $50 \%$ MUFA (od 51 do $64 \%$ ), 25 - 29\% SFA a 10 - 22\% PUFA. Filety lysce M2 $\times$ DOR70, lysce M2 $\times$ M72 a čisté linie M2 obsahovaly méně $(P<0.01)$ MUFA, zejména kyseliny olejové $\left(\mathrm{C} 18: 1_{\mathrm{n}-9}\right)$ a více $(P<0.01) \mathrm{PUFA}_{\mathrm{n}-3}$, zejména kyseliny eikosapentaenové $\left(\mathrm{C} 20: 5_{\mathrm{n}-3}\right)$ a dokosahexaenové $\left(\mathrm{C} 22: 6_{\mathrm{n}-3}\right)$. Rozdílné zastoupení mastných kyselin u jednotlivých skupin kaprů může souviset s jejich rozdílným genetickým vybavením.

\section{Acknowledgements}

This experimental study was supported by the Ministry of Education, Youth and Sports of the Czech Republic Research Plan "Veterinary aspects of food safety and quality" MSM 6215712402 and MSM 6007665809. The authors are also grateful to Ing. Milada Fialová and other workers from the Department of Chemistry and Biochemistry, Faculty of Agronomy, Mendel University of Agriculture and Forestry in Brno for the determination of fatty acids composition by GC.

\section{References}

Ackman RG 2000: Fish is more than a brain food. In International Institute for Fisheries Economics and Trade proceedings, pp. 1-6

Ackman RG 2002: Freshwater fish lipids-an overlooked source of beneficial long-chain n-3 fatty acids. Euro Fed Lipid 104: 253-254

Act legislation 2000: Act No 154/2000 of 17 May 2000 laying down rules for the improvement, breeding and registration of farm animals (Breeding Act). Collection of laws Czech Republic 49: 2274-2289

Application note 127/1990: The determination of fat in different kinds of fish. Tecator Sweden, pp. 1-3

Application note 300/2003: The determination of nitrogen according to Kjeldahl using block digestion and steam distillation. Foss Analytical AB Sweden, pp. 1-12

Buchtová H, Svobodová Z, Kocour M, Velíšek J 2009: Evaluation of amino acid composition in fillets of mirror crossbreds common carp (Cyprinus carpio, Linnaeus 1758). Acta Vet Brno 78: 337-344

Buchtová H, Svobodová Z, Křížek M, Vácha F, Kocour M, Velíšek J 2007: Fatty acid composition in intramuscular lipids of experimental scaly crossbreds in 3-year-old common carp (Cyprinus carpio, Linnaeus 1758). Acta Vet Brno 76: S73-S81

Corraze G, Larroquet L, Medale F 1993: Differences in growth-rate and fat deposition in 3 strains of rainbowtrout. Fish nutrition in practise 61: 67-72

Donmez M 2009: Determination of fatty acid compositions and cholesterol levels of some freshwater fish living in Porsuk Dam, Turkey. Chem Nat Compd 45: 14-17

Erickson MC 1992: Variation of lipids and tocopherol composition in three strains of channel catfish (Ictalurus punctatus). J Sci Food Agri 59: 529-536

Fajmonová E, Zelenka J, Komprda T, Kladroba D, Šarmanová I 2003: Effect of sex, growth intensity and heat treatment on fatty acid composition of common carp (Cyprinus carpio) fillets. Czech J Anim Sci 48: 85-92 
Folsch J, Lees M, Sloane-Stanley GH 1957: A simple methods for the isolation and purification of total lipids from animal tissues. J Biol Chem 226: 497-509

Gela D, Linhart O 2000: Evaluation of slaughtering value of common carp from diallel crossing. Czech J Anim Sci 45: $53-58$

Guler GO, Kiztanir B, Aktumsek A, Citil OB, Ozparlak H 2008: Determination of the seasonal changes on total fatty acid composition and $\omega 3 / \omega 6$ ratios of carp (Cyprinus carpio L.) muscle lipids in Beysehir Lake (Turkey). Food Chem 108: 689-694

Guo GL, Dong SL, Zhao W, Chen W 2008: Fatty acid composition of plankton and bighead carp (Aristichthys nobilis) in freshwater ponds. Clean 36: 209-215

Hoffman LC, Prinsloo JF 1995: Genetic and nutritional influence on the total lipid fatty acid profile of Clarias gariepinus muscle. Aqua Liv Res 8: 415-421

International Standard ISO 1442 1997: Meat and meat products: Determination of moisture content (Reference method). pp. 1-4

International Standard ISO 936 1998: Meat and meat products: Determination of total ash. pp. 1-6

Kocour M, Gela D, Rodina M, Linhart O 2005a: Testing of performance in common carp Cyprinus carpio L. under pond husbandry conditions I: top-crossing with Northern mirror carp. Aqua Res 36: 1628-1628

Kocour M, Linhart O, Gela D, Rodina M, Flajšhans M 2005b: The slaughtering value of all-female and bisexual populations of common carp (Cyprinus carpio L.) cultured in pond conditions of the Central Europe. Aquaculture 247: 20-21

Kocour M, Mauger S, Rodina M, Gela D, Linhart O, Vandeputte M 2007: Heritability estimates for processing and quality traits in common carp (Cyprinus carpio L.) using a molecular pedigree. Aquaculture 270: 43-50

Lachowicz K, Kołakowski E 2001: Wpływ sezonu połowu i stanu dojrzałości gonad na teksturę mięsa śledzi bałtyckich (Clupea harengus membras L.). Folia Univ Agric Stet 220: 53-58

Linhart O, Gela D, Rodina M, Šlechtová V, Šlechta V 2002: Top-crossing with paternal inheritance testing of common carp (Cyprinus carpio L.) progeny under two altitude conditions. Aquacult 204: 481-491

Mareš J, Palíková M, Kopp R, Navrátil S, Pikula J 2009: Changes in the nutritional parameters of muscles of the common carp (Cyprinus carpio) and the silver carp (Hypophthalmichthys molitrix) following environmental exposure to cyanobacterial water bloom. Aqua Res 40: 148-156

Simopoulos AP 1997: Omega-3 fatty acids and the prevention-management of cardiovascular disease. Can J Physiol Pharm 75: 34-239

Steffens W 1974: Chemische Zusammensetzung und Nährwert des Karpfenfleisches. Die Nahrung 18: 789-794

Steffens W 1997: Effects of variation in essential fatty acids in fish feeds on nutritive value of freshwater fish for humans. Aquacult 151: 97-119

Steffens W, Wirth M 2007: Influence of nutrition on the lipid quality of pond fish: common carp (Cyprinus carpio) and tench (Tinca tinca). Aquacult 15: 313-319

Steffens W, Wirth M, Füllner G 1998: Fatty acid composition of tench (Tinca tinca L.) under different nutritional conditions. Pol Arch Hydrobiol 45: 353-359

Trattner S, Ruyter B, Ostbye TK, Gjoen T, Žlábek V, Kamal-Eldin A, Picková J 2008: Sesamin increases alphalinolenic acid conversion to docosahexaenoic acid in atlantic salmon (Salmo salar L.) hepatocytes: Role of altered gene expression. J Lip Res 43: 999-1008

Zelenka J, Fajmonova E, Komprda T, Kladroba D, Šarmanová I 2003: Effect of dietary linseed and sunflower oil on cholesterol and fatty acid contents in rainbow trout (Oncorhynchus mykiss) fillets. Czech J Anim Sci 48: $321-330$ 